Michael NitZ, Alex GEORGE

Augustana College, USA

\title{
Stability and Change in the Heart of Europe: German Media Perspectives of the 2008 U.S. Presidential Election
}

\section{Introduction}

The 2008 U.S. Presidential election was a tale of stability and change. 1 Fears of an economic crisis and overall fatigue with eight years of the Bush Administration led to hope for change. Voters were faced with Senator John McCain, a war hero with a maverick reputation, or Senator Barack Obama, charismatic, yet with minimal experience. Finally, it was going to be an election of firsts- either the first female Vice President (Sarah Palin) or first African-American. In the end, Senator Obama won in a campaign that set numerous records.

This paper is interested in providing a glimpse into German news media framing of the 2008 U.S. Presidential election. More specifically, the paper is a case study that hopes to build on the work of international media coverage of political issues. First, justification for Germany is offered. Second, this is briefly discussed within a context of international media views of U.S. elections. Third, framing theory is proffered as a concept to explain German media coverage of the election. In particular, the importance of culture in the framing process is discussed.

\section{Germany}

Germany was a main stop on Obama's worldwide "educational" tour in the summer of 2008. Obama was perhaps the most beloved in Germany, with almost 80 percent support ${ }^{1}$. Hundreds of thousands turned out to hear Obama speak in Berlin. Germany has the highest population amongst Eu-

1 M. Winter, Das Streiflicht, “Sueddeutsche Zeitung”, November 8, 2008, p. 8. 
ropean Union countries and plays a significant role in organizations such as NATO and G8. Germany and the United States have shared a long friendship of cultural collaboration. Interestingly, some argue that Germany stands alone as the country with the most variety of love-hate relationships with the United States ${ }^{2}$. Given this role and influence, the manner in which the United States and its political system are framed in German media is worthy of study.

\section{Nature of German Media}

Although numbers are slowly declining ${ }^{3}$, Germany remains a country of avid newspaper readers. Germany has a diverse press landscape with a prestigious national press, and a number of highly developed regional and specialized papers ${ }^{4}$.

Several scholars have pointed to the subjective or partisan nature of the German press ${ }^{5}$. A trend continues to exist of analysis and interpretation in German media reporting, as well as more focus on the "game" or horse race strategy ${ }^{6}$. However, the German media have traditionally been good sources for political information. Semetko and Schoenbach cite percentages as high as 80 percent in terms of news coverage devoted to political stories ${ }^{7}$.

2 M. Emmer, G. Vowe, M. Seifert, Criticism of the USA and Anti-Americanism in Germany: A comparison of the influence of the media and first-hand experience. Paper presented at the annual meeting of the International Communication Association, Dresden, Germany, June 2006.

3 B. Scott, Global journalism in the world's regions: Western Europe, in: Global journalism: Topical issues and media systems, ed. A. de Beer, Pearson, Boston 2009.

4 F. Esser, K. Hemmer, Characteristics and dynamics of election news coverage in Germany, in: The handbook of election news coverage around the world, eds. J. Strömbäck, L. Kaid, Routledge, New York 2009.

5 W. Donsbach, Journalism research, in: German Communication Yearbook, eds. H. Brosius, C. Holtz-Bacha, Hampton Press, Cresskill, NJ 1999; C. Holtz-Bacha, Mass media and elections: An impressive body of research, in: German Communication Yearbook, eds. H. Brosius, C. Holtz-Bacha, Hampton Press, Cresskill, NJ 1999; R. Schmitt-Beck, Mass media, the electorate, and the bandwagon: A study of communication effects on vote choice in Germany, "International Journal of Public Opinion Research" 1996, no. 8, p. 266-292.

${ }^{6}$ F. Esser, K. Hemmer, op. cit.

7 H. Semetko, K. Schoenbach, Germany's unity election, Hampton Press, Cresskill, NJ 1994. 
Overall, the German news media play a crucial role in campaigns as tools for information. Most interesting for the transnational perspective in this paper is that prior interest leads to more exposure ${ }^{8}$. These high-interest citizens are actually more prone to become dependent upon mediated realities ${ }^{9}$, even in the face of personal experiences that might modulate such media perceptions ${ }^{10}$. This is consistent with those who note that attending to mass media is the principal means by which one becomes acquainted with the political world and develops opinion ${ }^{11}$.

\section{International Media Views of U.S. Elections}

This paper focuses on elections as a political issue. Political campaigns are news events that still matter and are a critical aspect of both political institutions and political communication research ${ }^{12}$. These campaign events mainly become visible to the public's eye through the media ${ }^{13}$. The media thus help shape perceptions of political institutions, the political process and political culture ${ }^{14}$. Unfortunately, election journalism has not been the ideal place for learning ${ }^{15}$. Culture becomes a primary basis for knowledge and meaning as a citizen understands these institutions or processes. Kunczik notes this is particularly the case with public perceptions

8 As above.

9 R. Schmitt-Beck, op. cit.

10 M. Emmer, G. Vowe, M. Seifert, op. cit.

11 K. Jamieson, Everything you think you know about politics... and why you're wrong, Basic Books, New York 2000.

12 H. Semetko, K. Schoenbach, op. cit.

13 K. Jamieson, op. cit.

14 U. Carlsson, Media and mass communication research-past, present, and future: Reflections from a Nordic horizon, "Nordicom Review" 2007, no. 28, p. 223-229; P. Curtin, T. Gaither, International public relations: Negotiating culture, identity, and power, Sage, Thousand Oaks, CA 2007; M. Luginbuehl, How culture shapes TV news: Notes on the Culturality of news stories in American and Swiss TV news since the 1960s. Paper presented at the annual meeting of the International Communication Association, Dresden, Germany, June 2006; T. Patterson, The press and its missed assignment, in: Election 88, ed. M. Nelson, Congressional Quarterly Press, Washington, D.C. 1988 .

15 T. Meyer, Media democracy: How the media colonize politics, Polity Press, Cambridge 2002. 
of political culture in other countries, where often the primary exposure one has is via images in the media ${ }^{16}$.

However, apart from a few studies ${ }^{17}$, little research has been conducted on cross or transnational perspectives of elections. Holtz-Bacha notes that most studies are "nationally orientated" within single countries ${ }^{18}$. Yet, comparisons in international contexts are important and campaigns are particularly amenable to such comparisons ${ }^{19}$.

This paper adopts a transnational perspective in that it examines news media images of the U.S. electoral process from abroad. World opinion about the U.S. is an 'ongoing process' of homogenization and diversification that affects international images of the U.S. and shifts in response to political events ${ }^{20}$. Media in different countries reflect distinct regional and national identities, interests, and policies ${ }^{21}$. These geopolitical and domes-

16 M. Kunczik, Images of nations and international PR, Erlbaum, Mahwah, NJ 1997.

17 B. Nacos, R. Shapiro, N. Hritzuk, B. Chadwick, New issues and the media: American and German news coverage of the global - warming debate, in: Decision making in a glass house: Mass media, public opinion, and American and European foreign policy in the $21^{\text {st }}$ century, eds. B. Nacos, R. Shapiro, P. Isernia, Rowman \& Littlefield, Lanham, MD 2000; M. Nitz, Ø. Ihlen, J. Egge, S. Sobolik, Transatlantic perspectives on the U.S. 2004 Election: The Case of Norway, "Nordicom Review" 2009, no. 30, p. 101-119; J. Strömbäck, D. Dimitrova, Political and media systems matter: A comparison of election news coverage in Sweden and the U.S., "Harvard International Journal of Press/Politics" 2006, no. 11, p. 131-147; H. Wu, Systemic determinants of international news coverage: A comparison of 38 countries, "Journal of Communication" 2009, no. 50, p. 110-130.

18 C. Holtz-Bacha, Political Communication Research Abroad: Europe, in: Handbook of Political Communication Research, ed. L. Kaid, Lawrence Erlbaum, New York 2004, p. 469.

19 G. Barnett, M. Lee, Issues in intercultural communication research, in: Handbook of international and intercultural communication, eds. W. Gudykunst, B. Moody, Sage, Thousand Oaks, CA 2002; J. Blumler, D. McQuail, Political communication scholarship: The uses of election research, in: Election Studies, eds. E. Katz, Y. Warshel, Westview, Boulder, CO 2001; A. Schorr, Communication research and media science in Europe: Research and academic training at a turning point, in: Communication research and media science in Europe, eds. A. Schorr, W. Campbell, M. Schenk, Mouton de Gruyter, Berlin 2003.

${ }^{20}$ F. Rusciano, Framing world opinion in the elite press, in: Framing terrorism: The news media, the government, and the public, eds. P. Norris, M. Kern, M. Just, Routledge, New York 2003, p. 175.

${ }^{21} \mathrm{H}$. Wu, op. cit. 
tic political perceptions are not limited to one country but also formulate about other countries ${ }^{22}$.

\section{Framing Theory}

Framing theory is a useful theoretical approach for analyzing media content ${ }^{23}$. Framing theory occupies an "important position in the international communication research agenda" 24 , namely because it extends research beyond the agenda setting tradition to focus on how issues are talked about. The media can have a strong impact in constructing social reality and frames of reference for the audience ${ }^{25}$ by drawing viewers' attention to issues and then subsequently nourishing frames by making more salient a particular attribute or set of attributes (Schenk, 2003). Framing is a way of making meaning by indicating which attributes are salient and implying a connection among those facts by: promoting a particular problem definition, causal interpretations, moral evaluation, and/or treatment recommendation, ..."26.

\section{Culture in Framing}

While there have certainly been a plethora of conceptualizations of frames, this paper focuses on the presence of culture in the framing process and is in accord with those who argue for "bringing culture

22 Framing terrorism: The news media, the government, and the public, eds. P. Norris, M. Kern, M. Just, Routledge, New York 2003.

23 R. Entman, Framing: Towards clarification of a fractured paradigm, "Journal of Communication" 1993, no. 43, p. 52-58; W. Gamson, Talking politics, Cambridge University Press, New York 1992; W. Gamson, A. Modigiliani, Media discourse and public opinion on nuclear power, "American Journal of Sociology" 1989, no. 95, p. 1-37.

24 C. de Vreese, Frames in television news: British, Danish, and Dutch television news coverage of the introduction of the Euro, in: News in a globalized society, ed. S. Hjarvard, NORDICOM, Gothenburg, Sweden 2001, p. 180.

25 C. de Vreese, The effects of frames in political television news on issue interpretation and frame salience, "Journalism and Mass Communication Quarterly" 2004, no. 81 , p. $36-53$.

26 R. Entman, op. cit., p. 52. 
back in"27. Culture is thought to be a key factor responsible for explaining and predicting variety among news frames and citizens' responses to such frames ${ }^{28}$. Culture "might be defined as the empirically demonstrable set of common frames-cognitive, affective, and behavioral - exhibited in the discourse and thinking of most people in a social grouping" 29 .

The media are a key arena in which this discourse takes place by privileging certain cultural frames or interpretations ${ }^{30}$. Consequently, media framing of these political events might explain the formation of cognitive and evaluative attitudes or orientations regarding institutional norms ${ }^{31}$. The media have influence in that they give an audience a way of understanding events through the production of forms or identities that culturally resonate with the audience's view of the world ${ }^{32}$. This paper supports the assertions of those who advocate that frames are comprised of several different dimensions or aspects that make up an overall package ${ }^{33}$. These frame packages are "clusters of organized devices that function as an identity kit" ${ }^{\prime 3}$. Culture can be a difficult concept to grip, but such a package approach can help uncover cultural patterns embedded in media content. Some examples of these elements are words, exemplars, and descriptions $^{35}$, reasoning devices such as causes or justifications ${ }^{36}$, and reasoning devices related to framing functions such as problem definition, moral

27 B. Van Gorp, The constructionist approach to framing: Bringing culture back in, "Journal of Communication" 2007, no. 57, p. 60.

28 A. Hansen, The media and the social construction of the environment, "Media, Culture, and Society" 1991, no. 13, p. 443-458.

29 R. Entman, op. cit., p. 52-53.

30 W. Gamson, op. cit.

31 G. Almond, The intellectual history of the civic culture concept, in: The civic culture revisited: An analytic study, eds. G. Almond, S. Verba, Little, Brown, Boston, MA 1980.

32 P. Curtin, T. Gaither, op. cit.; A. Jansson, Image culture: Media, consumption, and everyday life in Reflexive modernity, JMG, Gothenburg, Sweden 2001.

33 C. de Vreese, op. cit.; J. Strömbäck. D. Dimitrova, op. cit.; Ø. Ihlen, M. Nitz, Framing contests in environmental disputes: Paying attention to media and cultural master frames, "International Journal of Strategic Communication" 2008, no. 2, p. 1-18; H. Semetko, P. Valkenburg, Framing European politics: A content analysis of press and television news, "Journal of Communication" 2000, no. 50, p. 93-109.

34 B. Van Gorp, op. cit., p. 64.

35 W. Gamson, K. Lasch, The political culture of social welfare policy, in: Evaluating the welfare state: Social and political perspectives, eds. S. Spiro, E. Yuchtman-Yaar, Vol. 95, Academic Press, Paris 2003.

36 W. Gamson, A. Modigiliani, op. cit. 
evaluations, and treatment ${ }^{37}$. By themselves, these manifest elements are not necessarily an actual frame, but together in combination they provide a good heuristic tool to help complete a package that can point to certain latent cultural structures or frames ${ }^{38}$. Consequently, this paper argues that it is possible to use such an approach to analyze the framing of the 2008 U.S. Presidential election in German newspapers. The sections that follow present some of these package elements.

\section{Thematic/Episodic}

Iyengar's approach to framing theory suggests that news reports may be usefully analyzed by their thematic or episodic content ${ }^{39}$. Thematic news places events in a broader context of related events. In general, such stories do better at promoting learning and informing citizens. Episodic framing merely provides snapshots of an issue, with any explanations based on sensational or emotional appeals. Research shows episodic framing trivializes public discourse, discourages citizens from seeking links among issues and leads to the exclusion of many important issues ${ }^{40}$.

\section{Responsibility}

Iyengar's work also incorporates notions of responsibility. Causal responsibility addresses the source of a problem, while treatment responsibility addresses solutions. Individual attributions tend to be associated with episodic framing, while societal attributions tend to be associated with thematic framing ${ }^{41}$. A framing process where individuals are assigned blame does little to encourage rational decision-making or promote comprehension of a political process.

37 R. Entman, op. cit.

38 Ø. Ihlen, M. Nitz, op. cit.; B. Van Gorp, op. cit.

$39 \mathrm{~S}$. Iyengar, Is anyone responsible? How television frames political issues, University of Chicago Press, Chicago 1991.

${ }^{40}$ M. Nitz, H. West, Framing of newspaper news stories during a Presidential campaign cycle: the case of Bush-Gore in Election 2000, in: Environmental Communication Yearbook, ed. S. Senecah, Erlbaum, Mahwah, NJ 2004.

41 S. Iyengar, op. cit. 


\section{Image/Issue}

Research on media in election campaigns indicates that image-based political frames dominate ${ }^{42}$. Image-based frames, by concentrating on style over substance, lead to a more disconnected, episodic form of discourse $^{43}$. There is a widening trend in Europe of such an image-based or game focus in media coverage of campaigns ${ }^{44}$.

\section{Tone}

Iyengar notes that tone of coverage could be significant in shaping public opinion ${ }^{45}$. News stories can adopt a positive or negative tone towards individuals and societal institutions. A negative, adversarial tone in news accounts only breeds more cynicism and encourages voters to focus on character rather than issue substance ${ }^{46}$. This tone is not only present in headlines and articles, but also perhaps in the photos or visuals used to portray a story. These symbolic images help convey meaning and are effective at shaping public opinion and government policy ${ }^{47}$.

Type and Quality of Information

Despite the growing predominance of image in political campaigns, issues still matter in the context of how they help candidates play and win the game ${ }^{48}$. By focusing on a particular topic and ignoring others, the me-

42 K. Jamieson, op. cit.

43 T. Hollihan, Uncivil wars: Political campaigns in a media age ( $2^{\text {nd }}$ ed.), Bedford St. Martin's, Boston 2009.

44 F. Esser, K. Hemmer, op. cit.; H. Semetko, P. Valkenburg, op. cit., J. Strömbäck, D. Dimitrova, op. cit.

45 S. Iyengar, op. cit.

46 P. Moy, M. Pfau, With malice towards all? The media and public confidence in democratic institutions, Praeger, Westport, Ct 2000.

47 D. Graber, Seeing is remembering: How visuals contribute to learning from television news, "Journal of Communication" 1990, no. 40, p. 134-155; C. Smith, Visual evidence and environmental news: Case studies in the ethics of television news, Paper presented at the annual conference of the International Communication Association, Albuquerque, NM, May 1995.

48 K. Jamieson, op. cit. 
dia can help define problems and shape perceptions ${ }^{49}$. Certain cultural themes or frames may thus become more privileged. Relatedly, Paletz argues that it is not only important what issues are focused on, but also to examine the quality of this information ${ }^{50}$. Paletz breaks quality down along three dimensions-sophistication or depth of information, utility of information, and truth. Finally, in an attempt to tease out some more dimensions, this paper examines whether German journalists attempted to connect the U.S. election back to German culture. Illuminated aspects become a potential framework for understanding different cultures ${ }^{51}$. Emmer et al. point to some basic patterns of culture that extend over time in perceptions of the US through media such as materialism, superficiality, egoism/personality, freedom, leadership style, race, religion, conservative/liberalism and a variety of culture ${ }^{52}$.

\section{Research questions}

This paper is interested in how the 2008 U.S. Presidential election was framed in German newspapers. The following research questions attempt to explore the overall extent of this framing:

RQ1: Is German newspaper coverage predominantly thematic or episodic?

RQ2: What entities or individuals are assigned responsibility for causing problems and coming up with solutions?

RQ3: Do image or issue-based frames predominate in German newspaper coverage?

RQ4: What is the overall tone or bias?

RQ5: What is the nature of the type and quality of issue information?

RQ6: To what extent does newspaper coverage try to connect a story back to German culture (i.e. foci)?

49 K. Schoenbach, L. Becker, Origins and consequences of mediated public opinion, in: Public opinion and the communication of consent, eds. C. Salmon, T. Glasser, Guilford, New York 1995.

50 D. Paletz, The media in American politics, Longman, New York 1999.

51 A. de Beer, Global News: The fleeting, elusive but essential feature of global journalism, in: Global journalism: Topical issues and media systems, ed. A. de Beer, Pearson, Boston 2009; J. Galtung, M. Ruge, The structure of foreign news: The presentation of the Congo, Cuba and Cyprus crises in four Norwegian newspapers, "Journal of International Peace Research" 1965, no. 1, p. 64-91.

${ }^{52}$ M. Emmer, G. Vowe, M. Seifert, op. cit. 
These research questions stem from the work of those who advocate a package approach to framing analysis ${ }^{53}$.

\section{Method}

Election 2008 campaign stories from German newspapers were randomly collected during the fall campaign period. Election week editions from the newsstand were purchased during the first author's stay in Europe. These publications represented a wide selection of political viewpoints from several different regions of Germany. Only stories from the main news sections and editorial/opinion pages were included. A story was defined as each newspaper article, commentary/editorial, or feature about the U.S. Presidential election that listed a reporter's byline. Not every story was collected. Nonetheless, a representative sample of stories was collected. Coders were proficient in reading German and were trained beforehand.

The coding scheme was composed based on the framing elements mentioned below. While each element is examined separately, it is the taking together of these elements as a whole that hopefully conveys a glimpse of some patterns of underlying cultural frames or structures. This approach is consistent with those $\mathrm{s}^{54}$ who state that a series of manifest variables can represent a latent concept such as culture.

\section{Thematic-Episodic}

Stories were read in their entirety to determine whether they were predominantly thematic or episodic. If a story was judged to be two-thirds or more episodic, it was coded as episodic. An example of a thematic story would be a story on the background of the U.S. electoral system. An example of an episodic story would be a story that predominantly focuses on some isolated campaign incident such as Obama's choice of White House dog. A mixed category was included for those stories in which a predominant thrust could not be determined.

53 B. Van Gorp, op. cit.

54 K. Neuendorf, The content analysis guidebook, Sage, Thousand Oaks, CA 2002. 


\section{Responsibility}

Responsibility included both causal and treatment dimensions ${ }^{55}$. Causal responsibility referred to assignment of blame for a problem. Treatment responsibility referred to solutions for these problems. Once again, a two-thirds rule was utilized for coding, with a mixed category for those stories in which multiple attributions of responsibility occurred.

\section{Image/Issue}

Patterson's scheme ${ }^{56}$ that determines whether political stories are primarily image-based or issue-based was utilized. This scheme analyzed whether stories focused on frames of horse race coverage (who is winning or losing the game, polls), campaign issues (facts and rumors of scandals, dirty campaigning), campaign images (style of campaigning, personal appearance, likability), governing images (leadership ability, trust, knowledge/competence), policy (positions on issues), and candidate orientation (religious affiliation, personal background).

\section{Tone}

Stories were coded for their tone/bias in three separate areas of headlines, overall article, and any accompanying visuals. Stories were coded as positive if two-thirds or more of the story (headline, overall article, and accompanying visuals) referred to candidates and/or their policies in a positive manner. Stories were coded as negative if two-thirds or more of the story made predominantly negative references. This follows Ottosen's ${ }^{57}$ work which argues that one actually can make four separate judgments about two candidates (pro or anti for each). If it could not be judged whether a story was primarily negative or positive, a mixed category was included. Finally, a neutral category was included for those stories that simply portrayed an event, i.e. McCain campaigns in Iowa with no valua-

55 S. Iyengar, op. cit.

56 T. Patterson, op. cit.

57 R. Ottosen, The Norwegian media image of the war in Afghanistan: Peacekeeping or aggression?, "Nordicom Information" 2005, no. 1, p. 95-109. 
tion of that event. In addition, stories were coded (using the two-thirds rule) for overall tone towards the U.S.

\section{Type and Quality of Issue Information}

Stories were coded for the presence/predominance of issues. This category included specific issues such as war on terror, the economy, U.S./German relations. Campaign-related issues such as descriptions of the U.S. electoral system were included.

Coders also rated whether stories primarily focused on an individual, an issue, institutions/groups, or an overall country's culture. The quality of information was coded using Paletz's ${ }^{58}$ continuum of sophistication, utility, and truth of news information. Coders rated the stories for sophistication (did the story present different angles), utility (did the story help illuminate the relevance of an issue or was the story merely 'fluff'?), and overall truthfulness (did the story represent consensus about what was said, or were there distortions/embellishments of a trait or issue stance?). Coders identified the degree of connectiveness back to German culture (high, medium, or low), and the primary cultural focus (individual leadership style, freedom, conservative/liberal, capitalism/socialism, or some other aspect of society such as race, religion, or class).

\section{Results}

The present investigation attempted to provide a snapshot of media coverage of the U.S. 2008 Presidential election in major German newspapers. Overall, 161 stories were coded. There were 54 stories from the "Frankfurter Allgemeine Zeitung", 49 from "Die Welt", 33 from "Sueddeutsche Zeitung", 5 from "Bild Zeitung", and 19 from other daily papers. To determine whether coders reliably identified the instances of framing, three individuals independently coded a random sample of approximately 10 percent of the total instances. Inter-coder agreement was acceptable with $80 \%$ for the coding categories, and Cohen's kappa was acceptable ( $\hat{\mathrm{I}}=.64$.).

58 M. Paletz, op. cit. 
$R Q 1$

The first research question asked whether coverage would be primarily episodic or thematic. Results indicated that the majority of stories (56\%) were episodic, with 33 percent being thematic and 11 percent being mixed.

$R Q 2$

The second research question looked at the nature of responsibility for problems. When a problem for some current state of affairs was mentioned (the case in about 2/3 of all stories), President George W. Bush received the most blame (14\%). Other entities receiving blame were the U.S. government (13\%), U.S. culture/citizenry (11\%), the Republican party (9\%), John McCain (5\%), and Sarah Palin (4\%).

In terms of who is able to treat a problem, Obama was the clear winner (38\%). Even in stories where no one was assigned blame for a problem (or even in cases where no problem was mentioned); Obama was seen as the world's savior. The U.S. citizenry (11\%) came in second. The remainder of stories focusing on treatment responsibility dealt with the inept campaign being run by McCain and the Republicans. McCain, Palin, and the Republicans all received about 5 percent each of the treatment responsibility in stories.

$R Q 3$

The third research question asked about the predominance of issue/image frames. Horse race or game frames were predominant with 26 percent of all news stories reporting on how events impacted the election outcome. Specific policy issues, especially the economy, were second with 18 percent of stories. Governing images, campaign images, and candidate orientation/background each received about 15 percent of the focus in news stories. Finally, campaign issues received about 8 percent of the focus. $R Q 4$

The fourth research question analyzed the overall tone or bias in news coverage. Overall, German newspaper coverage presented a mixed (48\%) analysis of the U.S. election system. An example would be a story that highlighted Obama's success but then tempered this joy by noting how evil that system was and still is- Obama's election almost as revenge. Positive stories occurred about $16 \%$ of the time and negative four percent of the time. Approximately $1 / 3$ of news stories were neutral. 
In terms of the specific candidates, it should not be surprising that Obama received the most positive coverage (both in visuals and in text). Nearly one-third of all photos were pro Obama, with one-third being neutral. Photos did not appear in about $1 / 4$ of news stories. McCain was only portrayed positively in photos 3 three percent of the time.

Obama was predominantly portrayed positively in $1 / 4(25 \%)$ of news articles. No bias was present in about 27 percent of stories. As with overall tone, most German news stories presented a mixed picture (34\%). Finally, almost one-third $(29 \%)$ of headlines were pro Obama in nature. The remainder was either neutral $(41 \%)$ or mixed (17\%). Interestingly, 6 percent of headlines, the highest remaining total, were anti-Bush, even though he was not a candidate.

$R Q 5$

The fifth research question ascertained the type and quality of issue information present. Most stories displayed moderate (39\%) sophistication, with 32 percent of stories being low, and 29 percent of stories being high in sophistication. Again, most stories were moderate (45\%) in their degree of information utility. Almost 40 percent (38\%) were low in utility, with 17 percent being high in utility. Most stories were mixed (39\%) in their degree of truth. Nearly one-third (34\%) of stories were low in truth, with 27 percent being high in truth.

RQ6

The sixth research question tried to examine the degree of cultural connectivity back to Germany in several different categories. First, most stories did not (61\%) try to connect the US election back to Germany. Only 12 percent of stories attempted to discuss implications for Germany or compare/contrast with Germany. One-third (28\%) of stories presented a moderate amount of connectiveness.

In terms of cultural foci, there was a very high percentage (18\%) of stories that focused on race, with the primary angle being how Obama's election is either a dream or a vindication for years of inequity in the US system. One-fifth $(20 \%)$ of stories focused on the ego/personality of candidates. The democratic system or freedom received 16 percent of the focus. Stories with an angle about money in the political system occurred about 13 percent of the time. The nature of conservative/liberal politics in the USA was present in 7 percent of stories. About 5 percent of stories focused on the superficiality of a politician (usually McCain or Palin). 
Overall, there was a strong focus on the personalization of politics (37\%). US culture/country angle was present in about one-fourth of stories $(24 \%)$. Overall government system (19\%) was the focus in stories about the Electoral College, Wahlmaenner, etc. Specific policy discussion occurred in only about 12 percent of stories. Finally, leadership was presented mostly from a situational (34\%) viewpoint. Charisma (mostly Obama's) came next with 26 percent of the stories. The remainder was split evenly between maverick (13\%) and cool judge (11\%).

\section{Discussion}

This paper was a case study of how the 2008 U.S. Presidential election was framed in German newspapers. The paper echoes those ${ }^{59}$ who advocate the use of cultural frames as a strong heuristic tool in political communication. The importance and influence of culture in the framing process was stressed using a package approach. Taken together, the elements analyzed are potential indicators of underlying cultural frames or structures that were present in German newspaper coverage. The presence of such frame structures in German media texts could provide some elements of a symbolic language that culturally resonates "back home" with readers as they try to comprehend a different country's electoral system ${ }^{60}$. Examples of such elements were thematic/episodic framing, cultural connectivity, leadership style preference, race, personality, religion, conservative/liberal, and information quality/type.

Race was particularly interesting in the present study. It is probably most responsible for the moderate angle of information quality/type. German newspapers did a good job of reviewing the history of race in the United States. Several articles connected back to German political culture by asking not only is there a German Obama out there, but also is such a thing (minority rising to be leader of the country) even possible when one considers German history. This connectivity suffered somewhat by what seemed an overly strident focus on Obama's victory being revenge against an inherently racist, evil system.

German newspapers placed primary emphasis on the "Personalisierung" of the election. Individuals were presented and then analyzed as to

59 C. de Vreese, op. cit.; B. van Gorp, op. cit.

60 B. van Gorp, op. cit., P. Curtin, T. Gaither, op. cit. 
their impact on election outcomes. Stories would focus on Rahm Emanuel as the deal maker (pro and con), potential Cabinet picks, but mostly Obama as a person more than his issue stances. There is definitely an "Obamamania" present in Germany. Some headlines even had variations on this theme. Obama's approval ratings have actually gone up compared to the post-election euphoria ${ }^{61}$.

Some focus on personality produced some interesting nuances. For example, Obama was seen as the Savior of the world, but after reflection, he might challenge Germany to some policy changes. However, Palin was almost nonexistent and there was not one story on Biden. McCain was mostly presented as an angry old man flailing at windmills with his dirty tactics. Finally, even though George W. Bush was not running, a good handful of articles reserved some vitriol for him as causing a lot of these problems, including reflections on his leadership style. Overall, there was little, if any, connectivity back to German culture.

In terms of cultural focus, German newspapers presented a muddle picture of the U.S. political system. Several articles commented how "only in America" was such an election possible. On the other hand, critiques of the conservative political philosophy were very prominent. Perhaps this mix is indicative of what Emmer at al. cite as Germany's long love-hate relationship with the United States ${ }^{62}$.

Overall, the common symbolic language in 2008 that Germans could read in their newspapers was mainly structured around episodic, image-based frames that provided little, if any, quality information about the U.S. election. This fact could be exacerbated by findings indicating that German audiences may actually get less knowledge with higher interest and exposure ${ }^{63}$.

The cumulative results of this paper amplify the work of those ${ }^{64}$ who assert that media coverage of elections in other countries has a predominantly episodic focus of image-based horse-race or game frames. Hollihan ${ }^{65}$

${ }^{61}$ F. Seligman, Mr. President, listen to your German fans, "The Atlantic Times", no. 6, August 2009, p. 6 .

${ }_{62}$ M. Emmer, G. Vowe, M. Seifert, op. cit.

${ }^{63}$ H. Semetko, K. Schoenbach, op. cit.

${ }^{64}$ F. Esser, op. cit.; F. Esser, K. Hemmer, op. cit.; J. Strömbäck, D. Dimitrova, op. cit.; F. Esser, B. Pfetsch, Comparing political communication: Theories, Cases, and challenges, Cambridge University Press, Cambridge 2006; M. Nitz, Ø. Ihlen, J. Egge, S. Sobolik, op. cit.

${ }^{65}$ T. Hollihan, op. cit. 
argues that such a framing process hinders the chance for effective learning of political issues. One result could be a: trivialization of public discourse and the erosion of electoral accountability" ${ }^{\prime 66}$. Delli Carpini and Keeter believe "the quality of the public debate on issues depends critically on the nature of information brought to the information marketplace and the ability of citizens to use this information to discern and articulate interests" ${ }^{\prime 67}$. In modern democratic societies, citizens' information about political institutions (like campaigns) is mostly filtered through the mass media. Misperceptions of a political process (in this case the U.S. electoral system) could occur which may result in an incomplete understanding of a political culture and its institutions ${ }^{68}$. This case study argues that German newspapers presented the U.S. election from a series of cultural perspectives or frames that were not helpful in presenting a complete and accurate picture for understanding the U.S. political system.

This paper suffered from several limitations. First, the paper was limited in scope in that it focused on newspapers' coverage of one individual election. Trans and cross-national, perhaps longitudinal, comparisons would continue to be a fruitful avenue that expands on this. In addition, the paper was a content analysis that examined how the election was covered. Future research should connect such media framing analyses with surveys of these groups to provide a more complete picture of the influence of culture in the framing process.

\section{Conclusion}

This paper agrees with scholars who argue for more cross-national perspectives that explore the differences between U.S. and European framing of news, including elections ${ }^{69}$. The similarities in these perspectives can help understand and explain cultural frames present in different countries $=$ media. This paper supports the call of those ${ }^{70}$ that encourage future researchers to collaborate on excavating the frameworks of these struc-

66 S. Iyengar, op. cit., p. 143.

67 M. Delli Carpini, S. Keeter, What Americans know about politics and why it matters, Yale University Press, New Haven 1989, p. ix.

${ }^{68}$ G. Almonds, op. cit.

${ }^{69}$ C. de Vreese, op. cit.; J. Strömbäck, D. Dimitrova, op. cit.

70 P. Curtin, T. Gaither, op. cit. 
tures to find elements of common cultural identities that can create shared meaning.

\section{Streszczenie}

Artykuł analizuje treść publikacji prasowych na temat amerykańskich wyborów prezydenckich w $2008 \mathrm{r}$. jakie ukazały się w niemieckiej prasie. Artykuł posługuje się „pakietowym” (package) podejściem do kontekstu, obejmującego elementy składające się na kontekst bądź struktury kulturowe. Przedstawiono wyniki i płynące z nich wnioski dotyczące roli teorii framingu (kontekstu) w skali międzynarodowej. 